\title{
STUDENTS NARRATIVE ESSAY CONSTRUCTION ABILITY
}

\author{
Arbain \\ Fakultas Keguruan dan Ilmu Pendidikan \\ Universitas Widya Gama Mahakam Samarinda \\ email: baintigers@gmail.com
}

\begin{abstract}
The researcher conducted the research to (at) the third grade Students of SMK Negeri 9 Samarinda, which concerns to the Narrative Essay Construction Ability Made by the Twelve Grade Students of Fowl class. It is based on the researcher's experience when he was a teacher in SMK Negeri 9 Samarinda. During the researcher taught, he found that English achievement of fowl class is cukup (average), but they had problems in using grammar, especially present perfect tense.

In this study the researcher took 17 students as sample that were unique majoring for SMK in Samarinda and it is the only one in Samarinda. It is unique because breeding is usually a major in the university but now Samarinda has a vocational high school for learning animal cyclus.

This research revealed that the ability of narrative essay construction of the students of the fowl department is fair. It is shown by the mean score that they get, that is, 66.11. Second, almost all students of fowl department of SMK Negeri 9 Samarinda difficult to write a narrative essay in English well. It is shown by the percentage of the participants who get $\mathrm{C}$.
\end{abstract}

Keywords: Narrative, Essay, Construction

\section{INTRODUCTION}

One of the goal of vocational high school is able to create students as the output of the schools who can master well their specific skill of the major they choose. It will be a point plus for the students if their majoring-skill can be completed with good English in term of productive skills. One of the kind of productive skills in English is writing skills. In order to support the students in their learning process in the school especially in English subject, teachers should aware with the students skill as their object of the job. The teachers should take a note all aspects of English skills when teaching, hopefully those all aspects can be taught well.

One of the aspects of English that the students should comprehend well is active
English or active skills. Active skill refers to productive skill that is speaking and writing. Here, the writer emphasizes to conduct a research related to writing skill and It refers to writing subject Expressing ideas in wellorganized essay is essential to the success on writing. Through a good essay students can make their toughts clear to their readers. To be able to compose a good essay. However, students need some knowledge of what essay is, and later they are able to write one.

Hopefully by mastering writing skills, it can support their learning process in the school especially on English subject and as the additional skills that can be very useful in the future after they graduated from vocational high school besides their major skills based on their major they have chosen. In accordance 
with the statement above, the writer wants to do a research that enables him to know the ability of narrative essay construction of the Third Grade of Fowl Department students of Vocational High School (SMK) Negeri 9 Samarinda in academic year 2008/2009.

After having some investigation, the students of the Third Grade of Fowl Department of SMK Negeri 9 Samarinda are chosen because according to the writer it is a unique majoring for SMK in Samarinda and it is the only one in Samarinda. It is unique because breeding is usually a major in the university but now Samarinda has a vocational high school for learning animal cyclus. Besides, the writer is one of the English teacher there who has a very great motivation to improve student's English skill especially in writing subject.

It is also hoped that the study can describe the real ability of the students particularly the third grade students of fowl department of SMK Negeri 9 Samainda. So that the writer can observe the weaknesses of the students in the term of writing essays. Also it gives a suggestion for Mulawarman University particularly English language education department to provide English for specific purpose as one of the lesson should be taught for the collegers. English Language Education Department of Mulawarman University is famous as the campus which create English teachers to-be, to have a qualified English teachers to-be, the university should also provide English subject based on the needs in the school especially in vocational high school.

\section{METHOD}

The research of this research is a descriptive quantitative research. It is a descriptive design because it wants to describe the current phenomena found the field. Descriptive research involves a collection of techniques used to specify Cresswell (2012). Delineate, or describe naturally occurring phenomena without experimental manipulation.

This research is a quantitative research because the presentation of data and analysis uses statistic descriptive. In focuses are the mainly to raw score, mean and percentage.

The instrument used in this research is writing test. The test is in the form of assignment that is the participants are asked to write an essay with the topic "Experience during On the Job Training at Breeding". It is based on the majoring they choose.

\section{RESULT AND DISCUSSION}

This part shows the result of the research that has been conducted. After asking the participants to construct a narrative assay about experience on the job training, the researcher calculated the score.

The mean score of the content item is 20.27. According to ESL composition profile 20.27 is in the range of $21-17$. This range means fair. So, the content of the students' essay is fair.

Below is the sample of student's writing which content is fair:

Every morning I cleaned gallon or washed drinking water place, then in the bay day time I harvest egg and do vaccination in chicken. At 
11 o'clock we return to mess and have lunch with other friend and stable owner. Then afterwards we take a rest until around 2 o'clock. Correct 2 o'clock usually we go to stable to vaccination chickens and harvest egg. Afterwards usually we also always help to clean stable until 4 o'clock. After finished we are usually return home to mess to clean self afterwards we eat. At 6 o'clock usually stroll to look for comfort, usually go fishing place or go village other. Usually before evening arrive we also go to cafe to buy light food or bread, because if evening the road very dark, lonely and dark. There isn't any lamp in our PSG place so the place is really not pleasant. But we were accustomed to the loneliness and we could learn to be alive.

After around 4 months did the PSG, finally we finished also. After that we don't forget for stable photo with stable owner and other employee. Final after we give souvenir to stable owner and also give souvenir to us during psg there

Such experience psg that time. When is there deficit in my words this me apologize. For your kind attention I render thanks. (S.10)

Based on the student's writing above it reflects the content of the student's composition by looking at what sort of topic and how the student expresses his/her knowledge about the topic that he/she wrote. From the writing it shows that the student has limited knowledge of subject, it is seen from how he express the story about PSG experience. Little substance and inadequate development of topic, it is seen in too narrow point discussed.
The mean score of the organization item is 13.20. According to ESL composition profile 13.20 is in the range of $13-10.13-10$ means fair. So, the organization of the students' essay is fair.

Below the sample the organization of students' essay who get fair:

First time I fell so happy to get this experience. First day in my PSG, I prepare things and tool to DOC (anak ayam) that comes because when I come PSG DOC (anak ayam) many come. I bring Doc from the truck to our stable. I put DOC one by one and give DOC eat and drink. DOC also doesn't forget given sugar water to make DOC healthy. I must be give DOC routine eat and vitamin. After three day I also give vaccine to $5000 \mathrm{DOC}$ and I get experience to catch DOC. It was very difficult to take DOC and then I come to me to a rest. Everyday I gave eats and drinks to all of DOC (anak ayam) and clean stable. After 1 month I give more many eat than usual because chicken has been big. I give eat them every lunch and evening. I also help workers to harvest many chickens about 5000 chickens. I know price from agent, distributor and in the store. I get experience to keep chickens from DOC (anak ayam) until can harvest. I get too know the price from chickens and that was memorable. (S-13)

Based on the student's writing above it reflects the organization of the student's composition by looking at how the student organizes his/her essay. From the writing it shows that the student has limited knowledge in organization of essay. It is seen in some part of 
essay that consist many sentences disconnect each other. There are also some supporting sentences that aren't relevant with the topic sentence or with the main idea.

The mean score of the vocabulary item is 14.17. According to ESL composition profile 14.17 is in the range of $17-14.17-14$ means good. So, the vocabulary of the students' essay is good. Below the sample the vocabulary of students' essay who get good:

When we arrived at PT. Sadewo Farm, I was introduced to the head breeding and the other worker there. After that introduction, one of the workers sent us to our dormitory. Our dormitory was located not to far from the breeding and house workers. After put our goods, we came back to breeding to get instruction about our job. Our job was rather different. There were 2-3 and a worker in each breeding. The worker was to give instruction.

Our activities from 07.30-11.00 were:

Cleaning the water place

Giving chicken feed

Giving various medicines

Cleaning the stable

Taking eggs

There were so many stable at the breeding bur $t$ many of them were empty. The stables were divided into two kinds, postal and betray. My friend and I was placed at betray stable. We helped one of the workers there. We cleaned water place, gave chicken feed, and took the eggs then brought it to the warehouse. We got so many new knowledge and experience there.

At 11.00 O'clock we returned to our dormitory to have our lunch. After had lunch and took a 66 rest for a moment we came back to the breeding. We continued our job until 16.30 then we came back to dormitory.

We did our practical at PT. Sadewo Farm during four month. There were so many knowledge I got. After we finished our practical we returned to school to continue our study. (S3)

The student's writing above reflects the vocabulary of the student's composition by looking at the vocabulary that is used by the student to express his/her idea in the essay. From the writing it shows that the student has good vocabulary, it is seen from the vocabulary that is used by the student. In that essay, student frequently used effective word form and word order, and also correct usage that makes the meaning of the essay is clear.

The mean score of the language use item is 13.56. According to ESL composition profile 13.56 is in the range of $17-11.17-11$ means fair. So, the language use of the students' essay is fair.

Below the sample the language use of students' essay who get fair:

On February 4, 2008 I go to PSG together my friends in PT. Sadewo Farm. My first job is cleaning places of food that is fase grower. I also harvest eggs in Mr. Pitter. There are three students who PSG there. We help other employees job everyday.

As a girl, my job is not too difficult. I just take water and take all the eggs in the stable. After bay day, usually we take a rest and go to the mess to eat. We got free foods from the canteen in the mess. About 2 o'clock we go to stable again to take eggs. We wash and count its. 
Sometimes in the afternoon we take all the eggs more than two times because there are so many chickens there. I also to be vaccinator every week, we will give coryza and gumboro vaccine. My friends learn how to make good stable. If there are DOC (anak ayam) that come, we remove them to go to their stable. All the things will be difficult If there is DOC (anak ayam) that loose. We looking for them until night more over that place so cold and quietly. There are a few people in there. We just stay in the mess if the night come. We often follow my friends who go to fishing because in my mess so quiet and many people said that there is a ghost and all of my friends see but I never look it. Toilet in my mess so far from our room. If I want to go to there I always asked other to accompany me. Usually we go to there in the afternoon. We often given papaya by Mr. Pitter. He has many tree fruits. We feel so happy when rambutan season. We can eat many rambutan from the tree. I unfortunately when I throw wood to the tree and it fall in my head. I feel so confuse and take a rest a long three day. This is the end of my experiences in PSG. (S.11)

Based on the student's writing above it reflects the language use of the student's composition by looking at the language that is used by the student to develop his/her essay. In that essay, the student used very simple construction to show the problem and it also contain many mistake such as using error subject and verb agreement, using error word function and using incorrect pronouns. Besides, the student also used error tenses in almost sentences. The mean score of the mechanics item is 3.5. According to ESL composition profile 3.5 is in the range of 3. it means fair. So, the mechanics of the students' essay is fair.

Below the sample of the mechanics of students' essay who get fair:

On the morning, my friend and I gave chicken feed and water for chicken then I cleaned water placed and food place. On the afternoon I just gave water. It is because on the afternoon usually the weather was so hot, so that chicken needed more water. After that I didn't gave water or chicken feed again, I only controlled whether any chicken sick or die. After finished my job on that day, I took a bath and then watched TV with my friends. I slept at 10.00 $O$ 'clock to replace my energy.

I returned to breeding on tomorrow morning. My job was rather different than before. On that day I had to give vaccination for chicken. Before chicken got vaccination chicken didn't gave water and chicken feed around two hours. We mixed vaccine and water in a place then stirred it. After it was stirred well, we gave vaccine to chicken.

The day was evening when I finished giving vaccine to chicken, so I prepared my self to get home. I decided to sleep immediately so that I could get up earlier. (S-5)

The student's writing above reflects the mechanics of the student's composition by looking at mechanical used by the student to develop his/her writing. From the writing it shows that the student has limited knowledge in mechanical essay that it frequently errors of spelling, punctuations, and capitalization. It also consists only one paragraph so it makes the message in the essay cannot understand clearly. Based on the computation by using descriptive 
statistics focusing on the mean score and the percentage of the participants who get $\mathrm{A}, \mathrm{B}, \mathrm{C}$, $\mathrm{D}$, and $\mathrm{E}$. It is found that the mean score got is 66.11. The value of mean score then consulted to the classification of score in Mulawarman University. The mean score got is 66.11. It is in the degree of $60-69$.

The qualification is fair with the letter C. So that, the narrative essay construction ability made by third grade students of fowl Department of SMK Negeri 9 Samarinda in academic year $2013 / 2014$ is fair.

The result of the percentage computation is that the participants who get $\mathrm{A}$ is $12 \%$, the participants who get $\mathrm{B}$ is $12 \%$, the participants who get $\mathrm{C}$ is $70 \%$, the participants who get $\mathrm{D}$ is $6 \%$, the participants who get $\mathrm{E}$ is $0 \%$.

From the computation above, it can be concluded that the ability of the students of SMK N 9 Samarinda is fair. It can be describe that the ability of the students is still weak and should be increased. One way to increase the student's ability is by formulating new method in teaching learning process.

\section{Conclusion}

Based on the result of the research, the writer can concludes as follows:

The narrative essay construction ability is fair. The mean score of the writing is 66. It means that the mean score is in the range of $60-69,9$ based on the criteria of the scores applied in Mulawarman University and its qualification is fair. It indicates that most of the students are fair in writing a narrative essay in English is 70 $\%$.

The percentage of the participants who get $\mathrm{A}$ is $12 \%$, the percentage of the participants who get $\mathrm{B}$, the percentage of the participants who get $\mathrm{C}$ is $70 \%$, the percentage of the participants who get $\mathrm{D}$ is $6 \%$, and there is no percentage of the participants who get E. It means that the students are fair in written skill in the form of writing skill, in this case, writing narrative essay.

\section{Reference}

Arbain, A. (2017). Derivation in Headline Articles of the Jakarta Post Newspaper. IJOLTL, 2, 23-30. Retrieved from http://ijoltl.pusatbahasa.or.id/index.php/ij olt1/article/view/230

Brown, H. (2010). Language assessment (1st ed.). White Plains, NY: Pearson Education.

Creswell, J. W. (2012). Educational research: Planning, conducting, and evaluating quantitative and qualitative research. Educational Research (Vol. 4). https://doi.org/10.1017/CBO97811074153 24.004

Oshima, A.and Houge, A. 1997. Introduction to Academic Writing. Second Edition. New York. Addison Wesley Publishing Company.

Zemach, D, E and Rumisek, L, A. 2009. Academic Writing from Paragraph to Essay. Spain: Macmilan. 